\title{
Ophiuroidea (Echinodermata) from La Coronilla-Cerro Verde (Uruguay): a new record for the Uruguayan coast
}

\author{
Alvar Carranza ${ }^{1,2,4}$, Michela Borges ${ }^{3}$, Marcel Rodríguez ${ }^{2} \&$ Ana Inés Borthagaray ${ }^{1,2}$ \\ Biota Neotropica v7 (n3) - http://www.biotaneotropica.org.br/v7n3/pt/abstract?article+bn01607032007 \\ Data Received 22/01/07 \\ Revised 30/05/07 \\ Accepted 06/09/07 \\ ${ }^{1}$ Investigación \& Desarrollo, Iguá 4225, CP 11400, Montevideo, Uruguay, \\ ${ }^{2}$ Facultad de Ciencias, Iguá 4225, CP 11400, Montevideo, Uruguay \\ ${ }^{3}$ Departamento de Zoología, Instituto de Biologia, UNICAMP, CP 6109, \\ CEP 13083-970, Campinas, SP, Brazil, http://www.unicamp.br \\ ${ }^{4}$ Corresponding author: Alvar Carranza, \\ e-mail: alvardoc@fcien.edu.uy, http://imasd.fcien.edu.uy/,http://www.fcien.edu.uy/
}

\section{Abstract}

Carranza, A., Borges, M., Rodríguez, M. \& Borthagaray, A.I. Ophiuroidea (Echinodermata) from La Coronilla-Cerro Verde (Uruguay): a new record for the Uruguayan coast. Biota Neotrop. Sep/Dez 2007 vol. 7, no. 3 http://www.biotaneotropica.org.br/v7n3/pt/abstract?article+bn01607032007. ISSN 1676-0603.

La Coronilla-Cerro verde has been proposed as the first marine protected area in Uruguay. As part of a detailed benthic biodiversity assessment at the reserve, we analyzed the ophiuroid fauna collected in the intertidal and shallow subtidal during 2005 and 2006. Three species of ophiuroids were identified: Amphioplus lucyae, Amphipholis squamata and Amphiodia sp. Only two species belonging to the genus Amphiodia (A. pulchella and A. planispina) have been previously mentioned for Uruguayan waters, indicating that the unidentified species found in this study constitutes a previously unreported species.

Keywords: Amphiodia, Amphioplus, Amphipholis, Cerro Verde, marine protected area.

\section{Resumen}

Carranza, A., Borges, M., Rodríguez, M. \& Borthagaray, A.I. Ophiuroidea (Echinodermata) de La CoronillaCerro Verde (Uruguay): un nuevo registro para la costa uruguaya. Biota Neotrop. Sep/Dez 2007 vol. 7, no. 3 http://www.biotaneotropica.org.br/v7n3/pt/abstract?article+bn01607032007. ISSN 1676-0603.

La Coronilla-Cerro Verde ha sido propuesta como la primera área marina protegida del Uruguay. Como parte de un detallado análisis de la biodiversidad bentónica dentro de la reserva, se analizó la fauna de ofiuroideos colectada en el intermareal y submareal somero durante 2005 y 2006. Se identificaron tres especies: Amphioplus lucyae, Amphipholis squamata y Amphiodia sp. Solo dos especies del género Amphiodia han sido previamente mencionadas para la costa uruguaya (A. pulchella, y A. planispina) indicando que la especie de este género encontrada en este estudio corresponde a una especie aun no reportada.

Palabras clave: Amphiodia, Amphioplus, Amphipholis, Cerro Verde, área marina protegida. 


\section{Introduction}

The increasing need for an adequate environmental management, triggered by the conspicuous degradation of coastal habitats worldwide, has raised awareness of the need for systematic research to asses biodiversity. The need is especially acute for the marine invertebrates, particularly groups that may be sensitive indicators of environmental change (Thomas 1997, Basset et al. 2004). In Uruguay, coastal marine fauna is far from being completely documented, with little or no systematic effort directed toward taxonomic surveys and inventories of marine invertebrates. This lack of focus is further aggravated by the shortage of experienced field systematists and taxonomists (Scarabino 2006). Worldwide, the importance of detailed taxonomic inventories has been increasingly recognized (Gotelli 2004), since these constitute the basis for the development of ecosystem monitoring programs and the detection of environmental degradation.

Among the benthic invertebrates, the Echinodermata comprises nearly 6600 recent species, constituting one of the most important benthic groups worldwide (Hendler et al. 1995). The approximately 2000 species of ophiuroids are among the most widely distributed Echinodermata, occurring from polar regions to the tropics and from the intertidal to the abyssal plain (Hendler et al. 1995). Owing to their ubiquity and abundance, ophiuroids play an important role in energy transfer in benthic ecosystems, linking levels of local trophic webs (Summers \& Nybakken 2000).

Previously, the Uruguayan ophiuroidean fauna has been only studied on the continental shelf, from shallow environments (10 m) to $800 \mathrm{~m}$ on the slope area (Milstein et al. 1976, Lucchi 1985), with intertidal or shallow subtidal environments receiving little attention. Recently, Scarabino (2006) detailed all invertebrates (except mollusks) reported for Uruguayan shallow waters (i.e. $<50 \mathrm{~m}$ ), thus providing a basis to distinguish previously unreported species.

In this paper, we analyzed the ophiuroid fauna collected at the intertidal and shallow subtidal areas of Cerro Verde. La Coronilla-Cerro verde has been proposed as the first marine protected area in Uruguay, partially due to the existence of several research projects focused in different aspects of its biodiversity. Concerning benthic invertebrates, a detailed faunistic inventory is being performed at the intertidal and subtidal mussel beds and the submarine beach (Carranza \& Borthagaray 2005, Carranza et al. 2005, Borthagaray \& Carranza in press).

\section{Material and Methods}

\section{Study area}

Cerro Verde ( $33^{\circ} 57^{\prime} \mathrm{S}$ and $53^{\circ} 30^{\prime} \mathrm{W}$ ) is a rocky cape on the east coast of Uruguay (Figure 1). On each side of the cape there are sandy beach arcs that extend $2-3 \mathrm{~km}$. The coast experiences a semidiurnal tide (range $<0.5 \mathrm{~m}$ ) with the water level influenced mainly by wind conditions (direction and speed). Winds blow south-west during winter and north-east during summer. The rocky platforms have a smooth slope, with a width ranging from 15 to $23 \mathrm{~m}$, and are exposed to different degrees of wave action according to their orientation. Three zones, following the classical zonation schemes can be identified [on the platform]: a high intertidal zone dominated by a cyanobacterial film, a middle intertidal zone dominated by barnacles and a low intertidal and shallow subtidal zone characterized by a dense cover of mussels and/or macroalgae. Subtidal, deeper (>3-4 m) environments are dominated by sandy sediments (Milstein et al. 1976).

\section{Sampling design}

Sampling was carried out on intertidal and shallow subtidal (i.e. depth $<1.5 \mathrm{~m}$ ) rocky platforms of the Cerro Verde area dur-

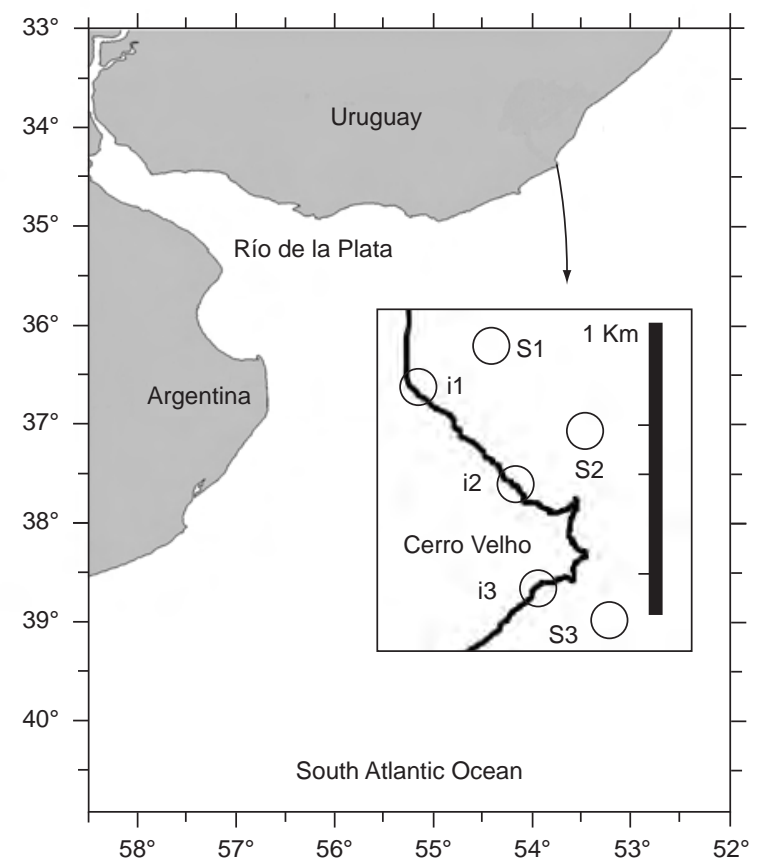

Figure 1. Map of South American Atlantic coast, showing the study region in the coast of Uruguay. Sampling sites: i1-i3: intertidal stations; S1-S3: subtidal stations.

Figura 1. Mapa de la costa Atlántica de Sudamérica, mostrando el área de estudio en la costa Uruguaya. Sitios de muestreo: i1-i3: estaciones intermareales S1-S3: estaciones submareales.

ing February 2005 and February 2006. Three sampling sites $500 \mathrm{~m}$ apart were chosen along the coast: 1) exposed, oriented S-SW, 2) intermediate, and 3) protected, oriented N-NE. Within each site, we randomly selected points at each dominance zone (mid intertidal, low intertidal and shallow subtidal), separated by 2 to $10 \mathrm{~m}$. In each point we placed one quadrat of $20 \times 20 \mathrm{~cm}\left(0.04 \mathrm{~m}^{2}\right)$ and collected all macrofauna and algae present using a metallic hand scrapper. In the shallow subtidal, three points were sampled by SCUBA divers, all in sandy bottoms: at each point, three samples were taken with a plastic corer of $15 \mathrm{~cm}$ diameter, each sample consisting in 5 cores. Organisms were fixed with formalin and, in the laboratory, identified and counted. Voucher material is deposited at Museo Nacional de Historia Natural y Antropología, Montevideo (MNHNM).

\section{Results}

A total of 13 specimens of ophiuroids, belonging to 3 species and 1 family (Amphiuridae) were collected. Two specimens were collected in the rocky intertidal and the remaining 11 at the shallow subtidal, in sandy bottoms ranging from 5-7 m depth. A detailed list of the examined material is provided below.

\section{Amphioplus lucyae}

Tommasi 1971 (Figure 2 a-c)

1.1. Examined material: 2 specimens: Size $2.6-3.8 \mathrm{~mm}$; Habitat: Shallow subtidal. (MNHNM 1705)

\subsection{Disk:}

Dorsal: Marginal interradial region showing a rectangular (= marginal) scale slightly larger than adjacent ones; radial shield cuneiform, separated and divergent (Figure 2a). Ventral: oral shields elongated; adoral shields stout and in contact proximally; four contiguous pa- 
pillae on each side of jaw and a pair of large, triangular, infradental papillae in the tip (Figure 2b,c).

\subsection{Arms:}

Dorsal arm plate trapezoidal (Figure 2a); ventral arm plate pentagonal; two tentacle scales (Figure 2b,c); four arm spines (Figure $2 b)$.

\section{Amphipholis squamata (Delle Chiaje 1828)}

(Figure 3 a-c)

2.1. Examined material: 2 specimens: Size $1.7-1.9 \mathrm{~mm}$; Habitat: rocky intertidal (MNHNM 1707)

\subsection{Disk:}

Dorsal: Primary scales not conspicuous; radial shields twice longer than wide, united. (Figure 3a).

Ventral: Oral shields anteriorly pointed, distally curved; adoral shields proximally in contact two oral papillae on each side of jaw, the distal papilla elongated and rectangular, and larger than the proximal papilla; a pair of elongated infradental papillae at the tip of the jaw (Figure 3b,c).

\subsection{Arms:}

Dorsal arm plate anteriorly pointed and distally curved (Figure 3a); ventral arm plate pentagonal; two tentacle scales (Figure $3 \mathrm{~b}, \mathrm{c}$ ); three arm spines (Figure 3b).

\section{Amphiodia sp. A}

(Figure 4 a-c)

3.1. Examined material: 9 specimens: Size 3.7-5.0 mm; Habitat: shallow subtidal (MNHNM 1706).

\subsection{Disk:}

Dorsal: Radial shields slightly longer than wider, united (Figure 4a).

Ventral: Oral shields rhomboidal, proximally elongated; adoral shields in contact proximally; two similar, rounded, oral papillae on each side of the jaw; a pair of rectangular infradental papillae, separated in the tip (Figure $4 b, c$ ).

\subsection{Arms:}

Dorsal arm plates rectangular, wider than longer, contiguous (Figure 4a); ventral arm plates quadrangular, contiguous; two tentacle scales (Figure 4b,c); three arm spines, slightly flattened, most notoriously in the ventral-most spine, larger and more compressed (Figure 4b).

\section{Discussion}

No species belonging to the genus Amphiodia other than A. pulchella and A. planispina has been mentioned for Uruguayan waters, indicating that the unidentified species found in this study constitutes a previously unreported species. Milstein and co-workers (1976) mentioned an unidentified species of the genus for the study area. Later, Lucchi (1985) assigned the specimens to A. planispina. Amphiodia sp. share similar characteristics with A. planispina, but differs from this species in showing only one flattened spine, the ventral-most one. A. planispina has three laterally compressed arm spines that are wider below the tip and very blunt. Amphiodia sp. differs of Amphiodia pulchella in several characteristics: size (Amphiodia sp. is larger, its adult reaching $12 \mathrm{~mm}$ ); adoral shields in contact proximally; dorsal arm plates rectangular (wider than longer) and three arm spines, slightly flattened, most notoriously in the ventral-most spine, larger and most compressed. In addition, $A$. pulchella is smaller (maximum adult size $=5 \mathrm{~mm}$ ), presents adoral shields separated proximally and its dorsal arm plates are not rectangular. Three arm spines can be identified, but the medial spine is dorsoventrally flattened, with a truncate, echinulate tip; the other two spines are bluntly rounded. However, until appropriate comparison
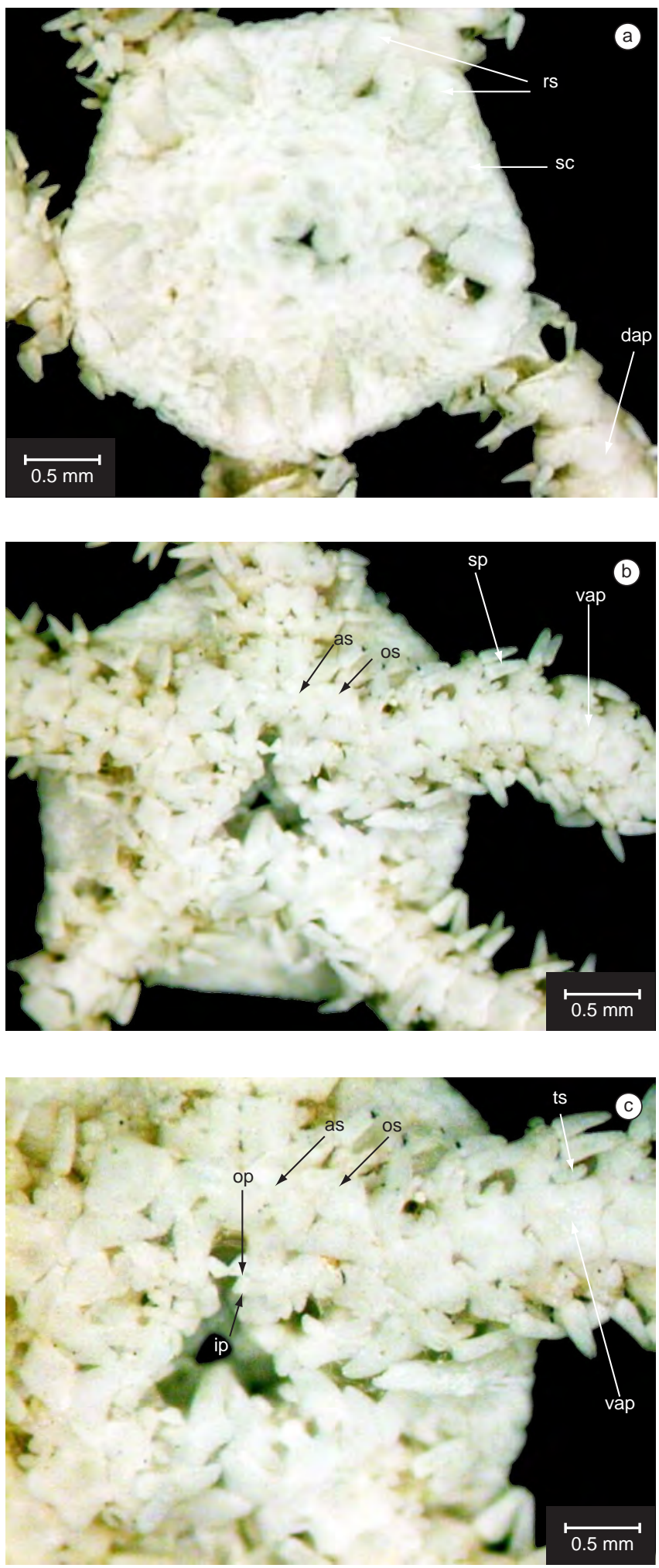

Figure 2. Amphioplus lucyae: a) dorsal view; b) ventral view; and c) detail of the oral frame. ip - infradental papillae; as - adoral shield; dap - dorsal arm plate; op - oral papillae; os - oral shield; rs - radial shield; rsc- retangular scale; sp - spines; ts - tentacle scale; vap - ventral arm plate.

Figura 2. Amphioplus lucyae: a) vista dorsal;b) vista ventral; y c) detalle del disco oral. ip - papila infradental; as- escudo aboral; dap- placa dorsal del brazo; op - papilas orales; os - escudo oral; rs - escudo radial; rsc - escama retangular; sp - espinas; ts - escama tentacular; vap - placa ventral del brazo. 

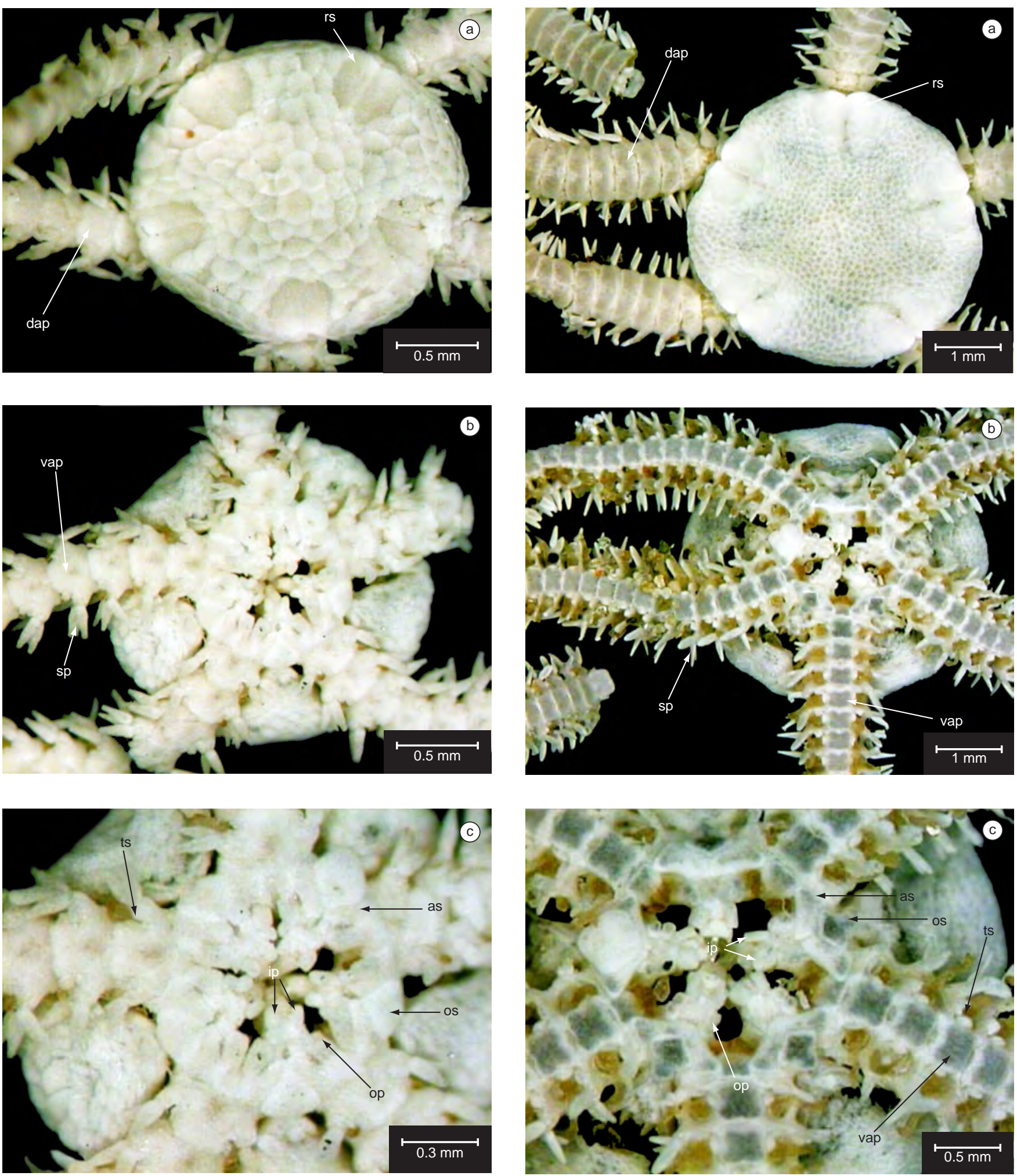

Figure 3. Amphipholis squamata: a) dorsal view; b) ventral view; and c) detail of the oral frame. ip - infradental papillae; as - adoral shield; dap - dorsal arm plate; op - oral papillae; os - oral shield; rs - radial shield; sp - spines; ts - tentacle scale; vap - ventral arm plate.

Figura 3: Amphipholis squamata. a) vista dorsal; b) vista ventral; y c) detalle del disco oral. ip- papila infradental; as- escudo aboral; dap- placa dorsal del brazo; op- papilas orales; os- escudo oral; rs- escudo radial; sp- espinas; tsescama tentacular; vap- placa ventral del brazo.
Figure 4. Amphiodia sp: a) dorsal view; b) ventral view; and c) detail of the oral frame. ip - infradental papillae; as - adoral shield; dap - dorsal arm plate; op - oral papillae; os- oral shield; rs - radial shield; sp - spines; ts - tentacle scale; vap - ventral arm plate.

Figura 4. Amphiodia sp: a) vista dorsal; b) vista ventral; y c) detalle del disco oral. ip - papila infradental; as - escudo aboral; dap- placa dorsal del brazo; op - papilas orales; os- escudo oral; rs - escudo radial; sp - espinas; ts - escama tentacular; vap - placa ventral del brazo. 
with specimens for Amphiodia species that have been reported from Brazil and Argentina we will not be able to suggest that it is an undescribed species. According to our samples, this species seems to be the more abundant ophiuroid in the area, with maximum estimated densities of $8.66 \mathrm{ind} / \mathrm{m}^{2}$.

To our knowledge, Tommasi et al. (1988b) constitutes the only previous known record of Amphioplus lucyae for the Uruguayan coast (R/V “Almirante Saldanha”, Station 2865, 34³3' S and 5312' W). This species was previously reported for southwestern Brazil (Tommasi 1971, 1999, Monteiro 1987, Borges et al. 2002). Tommasi and coworkers (1988a, 1988b), Monteiro (1987, 1990, 1997) and Borges et al. (2002) reported A. lucyae at depths ranging from 8-600 m. We collected this species only in one subtidal sample (depth 5-7 m), suggesting low population densities at the area (maximum density $<5$ ind $/ \mathrm{m}^{2}$ ).

A. squamata is an euribathic, cosmopolitan species, recorded worldwide with Atlantic records from Florida (USA) to Argentina, occurring from 0 to $1330 \mathrm{~m}$ (Hendler et al. 1995), and associated to different biological substrata such as algae, bryozoans, and sponges (Borges \& Amaral, 2005). Tommasi and co-workers (1988b) already reported this species for the Uruguayan coast, while Milstein and coworkers (1976) reported specimens from subtidal environments of our study area. Alves \& Cerqueira (2000) reported intertidal records for this species, as did Bernasconi (1926) for the Argentinean coast. In this study, this species occurred exclusively in the rocky intertidal, associated with mussel banks dominated by Brachidontes rodriguezii and Perna perna, constituting the first record of this species in this particular habitat for the Uruguayan coast. Most likely, the sediment layer occurring between the mussel layer and the rock surface allows the presence of ophiuroids. This species seems to be rare in the mussel banks of the study area, as indicated by the low frequency of occurrence $(0.01 \%$ of total intertidal samples).

We strongly stressed the need for detailed taxonomic studies on other benthic invertebrates at the study area, aiming to provide a precise taxonomic inventory of the benthic fauna within the reserve area.

\section{Acknowledgments}

The field work was supported by The Maurice Laing Foundation Rufford Small Grant for Nature conservation. SCUBA divers Pablo Píriz and Jorge Duran and Dr. Danilio Calliari are acknowledged for collaboration during field work. We also thank F. Scarabino for the valuable comments made on an earlier version of the manuscript. Our thanks to the Departamento de Zoologia, Instituto de Biologia, UNICAMP, for the facilities and assistance with figures. Two anonymous reviewers are acknowledged for their very helpful suggestions.

\section{References}

ALVES, O.F.S. \& CERQUEIRA, W.R.P. 2000. Echinodermata das praias de Salvador (Bahia, Brasil). Rev. Bras. Zool. 17:543-553.

BASSET, A., SANGIORGIO, F. \& PINNA, M. 2004. Monitoring with benthic macroinvertebrates: advantages and disadvantages of body size descriptors. Aquat. Conserv. 14:S43-S58.

BERNASCONI, I. 1926. Una ofiura vivípara de Necochea. An. Mus. Hist. Nat. (Buenos Aires). 34:145-153.

BORGES, M. \& AMARAL, A.C.Z. 2005. Classe Ophiuroidea.. In Manual de Identificação dos Invertebrados Marinhos da Região Sudeste-Sul do Brasil. (A.C.Z. AMARAL, A.E. RIZZO \& ARRUDA, E.P. eds). Vol. I. EDUSP Ed. São Paulo. p. 238-272
BORGES, M., MONTEIRO, A.M.G. \& AMARAL, A.C.Z. 2002. Taxonomy of Ophiuroidea (Echinodermata) from the continental shelf and slope of the Southern and Southeastern brazilian coast. Biota Neotropica, 2:1-69 http://www.biotaneotropica.org.br/v2n2/pt/fullpaper?bn02302022002_ 1+pt (last accesss in 14/12/2006).

BORTHAGARAY, A.I. \& CARRANZA, A. In press. Mussels as ecosystem engineers: Their contribution to species richness in rocky littoral community. Acta Oecol. Int. J. Ecol.

CARRANZA, A. \& BORTHAGARAY, A.I. 2005. Los mejillones como ingenieros ecosistémicos: su contribución a la riqueza especifica en la comunidad del litoral rocoso. Publ. Esp. Soc. Zool. Uruguay. Act. VIII. Jorn. Zool. Uruguay. 65 [Abstract]

CARRANZA, A., BORTHAGARAY, A.I. \& GENZANO, G.N. 2005. Dos nuevos registros de Pycnogonida para aguas Uruguayas. Publ. Esp. Soc. Zool. Uruguay. Act. VIII. Jorn. Zool. Uruguay. 49 [Abstract].

GOTELLI, N.J. 2004. A taxonomic wish-list for community ecology. Philos. Trans. R. Soc. Lond., B, Biol. Sci. 359:585-597.

HENDLER, G., MILLER, J.E., PAWSON, D.L. \& KIER, P.M. 1995. Sea stars, sea urchins and allies: echinoderms of Florida and the Caribbean. Smithsonian Institution Press, Washington.

LUCCHI, C. 1985. Ophiuroidea (Echinodermata) del frente marítimo uruguayo hasta $800 \mathrm{~m}$ de profundidad, con claves para su reconocimiento. Contrib. Depto. Oceanogr. (F.H.C), Montevideo, 2:115-171.

MILSTEIN, A., JUANICÓ, M. \& OLAZARRI, J. 1976. Algunas asociaciones bentónicas frente a las costas de Rocha, Uruguay. Resultados de la campaña del R/V "Hero", viaje 72-3ª Com. Soc. Malac. Urug. 4:143-164.

MONTEIRO, A.M.G. 1987. Ophiuroidea (Echinodermata) da região de Ubatuba (SP) - Aspectos morfológicos e ecológicos. Tese de Doutorado, Universidade de São Paulo, São Paulo.

MONTEIRO, A.M.G. 1990. Ophiuroidea (Echinodermata) in the coastal system of the State of São Paulo (Brazil). In Anais II Simpósio de Ecossistema da Costa Sul e Sudeste Brasileira: Estrutura, Função e Manejo, v.1. Águas de Lindóia, p.186-201.

MONTEIRO, A.M.G. 1997. Ocorrência de Ophiuroidea (Echinodermata) na plataforma do Estado de São Paulo. In Boletim de Resumos Expandidos VII COLACMAR, Santos, v.2, p. 182-183.

SCARABINO, F. 2006. Faunística y taxonomía de invertebrados bentónicos marinos y estuarinos de la costa uruguaya. In Bases para la conservación y el manejo y de la costa uruguaya (R. Menafra, L. Rodríguez-Gallego, F. Scarabino \& D. Conde, eds). VIDA SILVESTRE (Sociedad Uruguaya para la Conservación de la Naturaleza), Montevideo, p. 113-142.

SUMMERS, A.C. \& NYBAKKEN, J. 2000. Brittle star distribution patterns and population densities on the continental slope off Central California (Echinodermata: Ophiuroidea). Deep Sea Res. Part II Top. Stud. Oceanogr. 47:1107-1137.

THOMAS, J.D. 1997. Using Marine Invertebrates to Establish Research and Conservation Priorities. In Biodiversity II: Understanding and Protecting Our Biological Resources (M. L. Reaka-Kudla, D. E. Wilson, E. O. Wilson, eds.) Joseph Henry Press, London, p. 357-370.

TOMMASI, L.R. 1971. Equinodermes do Brasil. I. Sobre algumas novas espécies e outras pouco conhecidas para o Brasil. Boletim do Instituto Oceanográfico, Universidade de São Paulo, 20:1-21;

TOMMASI, L.R., CASTRO, S.M. \& SOUSA, E.C. 1988a. Echinodermata coletados durante as campanhas oceanográficas do N/Oc. "Almirante Saldanha" no Atlântico Sul Occidental. Relat. Interno Inst. Oceanogr. Univ. Sao Paulo. 21:1-11

TOMMASI, L.R. 1999. Echinodermata Recentes e Fósseis do Brasil. http:// www.bdt.org.br/zoologia/echinodermata/ 12/12/2005

TOMMASI, L.R., CERNEA, M.C.W. \& CONDEIXA, M.C.G. 1988b. Equinodermes coletados pelo N/Oc. "Almirante Saldanha" entre $26^{\circ} 59^{\prime} \mathrm{S}$ e $38^{\circ} 39^{\prime}$ S. Relat. Interno Inst. Oceanogr. Univ. Sao Paulo. 22:1-11 
